\title{
MEN AND COVID-19: EXPLICATING THE NEED FOR MASCULINITY ANALYSIS
}

\author{
Anisur Rahman KHAN1 \\ Kopano RATELE ${ }^{2}$ \\ DOI: $10.35782 / J C P P .2021 .1 .01$
}

\begin{abstract}
There are important gender determinants to both men's and women's susceptibility to COVID-19. Emerging findings confirm men are dying disproportionately at a bigher rate than women. Such gender differences in deaths have informed scholars to widen their analytical look through a critical masculinity lens. As the practices to respond to the context of the gendered burden of disease are still inadequate and nearly absent on men's health, it is suggested to specifically focus on men's vulnerability to COVID-19 with appropriate interventions.
\end{abstract}

Keywords: COVID-19, gender, masculinity, men's health, domestic violence, suicide

\section{Introduction: Men's vulnerability to COVID-19}

The COVID-19 has brought an unusual type of outbreak and complexities for which the world was not prepared. The pandemic, and the incredible speed at which the virus is spreading, has prompted us to call for academic and policy analyses and interventions using critical masculinity lenses given that the disease outbreak is not gender-neutral: it affects women and men differently (Durant, 2020). Assessing the jolt of the COVID-19 pandemic on at-risk groups, coupled with a masculinity perspective, is indispensable for establishing efficient and responsive policies and interventions (Wenham, Smith \& Morgan, 2020). Understanding the interface between men's gender socialisation and masculinity ideologies in relation to their health-related risks and protective factors could provide useful messages in prevention initiatives (Garfield, Isacco \& Rogers,

1 Department of Sociology, East West University, Dhaka-1212, Bangladesh; e-mail: arkhan@ewubd.edu; phone: +8801939240971

2 Masculinity and Health Research Unit, South African Medical Research Council-University of South Africa/ Institute for Social and Health Sciences, University of South Africa, Cape Town, South Africa; e-mail: kopano.ratele@mrc.ac.za 
2008). And yet, when it comes to men's health and perspectives, policies and interventions to respond to the context of the gendered burden of disease are still inadequate and, in some countries, absent (Purdie et al., 2020). A mistaken assumption that policies and programs to address gender issues should predominately encompass women's perspectives and concerns persist (Nkangu, Olatunde \& Yaya, 2017).

Although global sex-disaggregated data on COVID-19 is still not uniformly available, country-specific sources, including those from the shifting epicenter of the outbreaks, namely China, Italy, Spain, USA and UK, indicated that men are dying at a higher rate than women (Baker, 2020; Purdie et al., 2020; Jin et al., 2020; Mooney, Kaplan \& Denis, 2020). Global Health 50/50 (as of 28 May 2020) has shown that whilst there is no clear pattern regarding whether women or men are more likely to be infected by COVID-19, evidence reveals that more men than women are dying from COVID-19 in all countries. Men appear to be $50 \%$ more likely than women to die after being diagnosed with COVID-19 positive (Global Health 50/50, nd.). It is noteworthy that men's higher morbidity was also evident during the earlier outbreaks such as Severe Acute Respiratory Syndrome (SARS) and Middle East Respiratory Syndrome (MERS) (Purdie et al., 2020), and Ebola (Nkangu et al., 2017).

\section{Male Norms in Action}

The reasons for men's higher susceptibility to dying from COVID-19 remain unclear (World Bank Group, 2020). However, the complexities and interactions associated with biology (i.e., sex) and social practice (i.e., masculinity) appear to be strongly associated with men's elevated susceptibility (Global Health 50/50, nd; van Osch, 2020). While biological factors such as stronger immune systems appear to give women more protection than men, several factors associated with masculinity practices make men more vulnerable during disease outbreaks (van Osch, 2020; World Bank Group, 2020). Masculinity as a sociological concept does not entail any fixed entity embedded in bodies or behavioral traits. It differs across economic, cultural and temporal settings, tied to prevailing social gender relations in place (Connell \& Messerschmitt, 2005). Usually, it refers to certain physical, behavioral and attitudinal qualities that are essential to be a man in a particular historical, social and cultural milieu (Mason-Grant, 2000). Men's health problem is a part of their gender role socialisation, as men who hold more traditional masculine norms are more likely to be involved in health-impeding behaviors and less likely to be involved in health-promoting behaviors (Garfield et al., 2008). Men tend to involve in high risk-driving behaviors such as higher levels of drug, alcohol and tobacco consumption. They also tend to hide their vulnerability and are reluctant in self-care and medical/professional help-seeking (Mahalik, Burns \& Syzdek, 2007). Conversely, women's gender role socialisation supports them to involve in more health-promoting behaviours than men and maintain more healthy lifestyles. Such practice conceivably ensures more prevention and protection for women during healthrelated adversities (Courtenay, 2000b), and at the moment, a lower risk than men to death from COVID-19 pandemic. 


\section{Specific Evidential Impacts}

Such restrictive expectations and role deviations could be health-damaging for men, but could also be disastrous for women, children and other members of the family. Emerging data indicate that domestic violence against women has increased during this global pandemic - a situation that is called by UN Women "a shadow pandemic" (UN Women, 2020). Domestic violence reflects unjust patriarchal and harmful gender norms. Some men are experiencing pressures and difficulties with their power dynamics because of being at home under lockdown. At the same time, in times of high stress and uncertainty, patriarchal gender constructions and dynamics can be disrupted. As a result, patriarchal men can resort to violence against intimate partners (Molano, 2020). Perpetuating violence is a longstanding method of demonstrating or reinstating manhood or masculinity (Hearn, 1998). Therefore, promoting nonviolent nonpatriarchal masculinities has been indicated as a key item on the violence prevention agenda during COVID-19 period (UN Women \& WHO, 2020). Engaging men and boys in critical discussions during this period is expected to play an important role in promoting healthy and non-violent behaviors (Betron, Gottert, Pulerwitz, Shattuck \& Stevanovic-Fenn, 2020).

An area of special concern is the nexus between COVID-19 pandemic and male suicide. Emerging research reports also confirm men are dying at a higher rate than women from suicide during the Covid-19 pandemic (Thakur \& Jain, 2020; Mamun \& Ullah, 2020). Several direct and indirect triggering factors such as financial and future insecurities, fear of infections, social stigma, anxiety and excessive regulations, among others, stand behind male suicidality during COVID-19 (Thakur \& Jain, 2020; Mamun \& Ullah, 2020; Khan, Ratele \& Najuwa, 2020). Globally suicide is considered as a masculine act (Cleary, 2012). There is a striking gender difference in suicide rates worldwide, with men accounting for higher deaths by suicide than women. Male suicide rates are at 15.6 persons per 100000 population, whereas females are at 7 persons per 100000 population (Naghavi, 2019). Given the sexed/gendered nature of suicidal behaviours, during and following COVID-19 crisis suicide prevention efforts ought to pay specific attention to the heightened male vulnerability because male suicidal behavior is often embedded in deepest emotions and despairs resulting from masculine deficiencies or inadequacy associated with the traditional masculine role expectations (Khan, Ratele, Helman, Dlamini, \& Makama, 2020). Furthermore, the risks associated with male suicidality are always higher as men feel restrained to disclose disturbing feelings and emotional pains to family members, peers and health care professionals due to adherence to strong traditional masculine norms (Cleary, 2012).

\section{Conclusion: Way Forward}

While there is no evidence as of yet, it could be that it is especially those men who subscribe to hegemonic socio-cultural ideas and presumptions of cisgender construction who are likely to suffer during COVID-19 pandemic and possibly in the immediate post-COVID-19 pandemic future. At the same time, some men who subscribe to traditional masculinity may be putting themselves at risk through engaging in risky behaviors such as disregarding social distancing, hand-washing, and mask- 
wearing rules, among others. What is slowly emerging from news media across the world is that while those in occupations in which working from home or online is possible may survive, occupations traditionally associated with masculinity are also being swiftly worn away during the coronavirus catastrophe. There are massive job losses globally. There are reports of increased poverty and hunger rates in countries from the Global South and even from the Global North. Consequently, the status of being the primary breadwinner for the family will be put under even more pressure.

Therefore, extensive efforts are needed to minimise the implications of men's traditional masculinity practices that will give them more social, economic and healthrelated immunity during COVID-19. This crisis can be taken up as an opportunity to topple the trouble, expectation and burden associated with men as head of household and breadwinner through promoting shared caregiving roles and responsibilities between women and men with equal importance (Betron et al., 2020). It is imperative to promote notions of positive masculinity through a range of media and digital platforms and make drives against restrictive male-female gender dichotomisation. There is no alternative during this crisis to create space for men to speak out of their sufferings and trauma, and to break the shackle of traditional masculinity. Policy interventions must aptly recognise men's needs, sufferings and diversities and measures must be in place to eliminate the barriers men face in accessing services during the COVID-19 pandemic (Betron et al, 2020).

\section{References}

Baker, P. (2020). Call for global evidence on gender and COVID-19. Retrieved from https://www.menshealthforum.org.uk/news/call-global-evidence-gender-and-covid-19.

Betron, M., Gottert, A., Pulerwitz, J., Shattuck, D. \& Stevanovic-Fenn, N. (2020): Men and COVID19: Adding a gender lens. Global Public Health. https://doi.org/10.1080/17441692.2020.1769702

Cleary, A. (2012). Suicidal action, emotional expression, and the performance of masculinities. Social Science \& Medicine, 74(4), 498-505. https://doi.org/10.1016/j.socscimed.2011.08.002

Connell, R.W, \& Messerschmitt, J.W. (2005). Hegemonic masculinities: Rethinking the concept. Gender and Society, 19(6), 829-859. https://doi.org/10.1177\%2F0891243205278639

Courtenay, W. H. (2000b). Constructions of masculinity and their influence on men's well-being: a theory of gender and health. Social Science \& Medicine, 50(10), 1385-1401. https://psycnet.apa.org/doi/10.1016/S0277-9536(99)00390-1

Durant, I. (2020). COVID-19 requires gender-equal responses to save economies. Retrieved from https://unctad.org/en/pages/newsdetails.aspx?OriginalVersionID=2319.

Garfield, C. F., Isacco, A., \& Rogers, T. E. (2008). A review of men's health and masculinity. American Journal of Lifestyle Medicine, 2(6), 474 487. https://doi.org/10.1177/1559827608323213

Global Health 50/50 (nd). COVID-19 sex-disaggregated data tracker. Retrieved from https://globalhealth5050.org/covid19/.

Hearn, J. (1998). The violences of men: How men talk about and how agencies respond to men's violence to women. London, UK: SAGE.

Jin, J-M., Bai P., He, W., Wu, F., Liu, X-F., Han, D-M, Liu, S., \& Yang, J-K., (2020). Gender differences in patients with COVID-19: focus on severity and mortality. Frontiers in Public Health, 8, 152. https://doi.org/10.3389/fpubh.2020.00152 
Khan, A., Ratele, K., \& Arendse, N. (2020). Men, Suicide, and Covid-19: Critical Masculinity Analyses and Interventions. Postdigital Science and Education, 2(3), 651-656. https://doi.org/10.1007/s42438020-00152-1

Khan, A. R., Ratele, K., Helman, R., Dlamini, S., \& Makama, R. (2020). Masculinity and Suicide in Bangladesh. OMEGA - Journal of Death and Dying, 0030222820966239. https://doi.org/ 10.1177/0030222820966239

Mahalik, J. R., Burns, S. M., \& Syzdek, M. (2007). Masculinity and perceived normative health behaviors as predictors of men's health behaviors. Social Science \& Medicine, 64 (11), 2201-2209. https://doi.org/10.1016/j.socscimed.2007.02.035

Mamun, M., \& Ullah, I. (2020). COVID-19 suicides in Pakistan, dying off not COVID-19 fear but poverty? - the forthcoming economic challenges for a developing country. Brain, Behaviour, and Immunity. https://doi.org/10.1016/j.bbi.2020.05.028

Mooney, C., Kaplan, S., \& Denis, B. (2020). All across the United States, the coronavirus is killing more men than women, data show. The Washington Post, April 05. https://www.washingtonpost. com/health/2020/04/04/coronavirus-men/. Accessed 29 May, 2020

Molano, S. (2020). Men, masculinity, violence and care in times of Covid-19. Retrieved from https://www.defyingenderoles.org/master-in-love/2020/4/16/men-masculinity-violence-andcare-in-times-of-covid-19.

Naghavi, M. (2019). Global, regional, and national burden of suicide mortality 1990 to 2016: Systematic analysis for the global burden of disease study. British Medical Journal, 364, 194. https://doi.org/10.1136/bmj.194

Nkangu, M.N., Olatunde, O.A., \& Yaya, S. (2017). The perspective of gender on the Ebola virus using a risk management and population health framework: A scoping review. Infectious Diseases of Poverty, 6 (1), 135. doi:10.1186/s40249-017-0346-7

Purdie, A., Hawkes, S., Buse, K., Onarheim, K., Aftab, W., Low, N., \& Tanaka, S. (2020). Sex, gender and COVID-19: disaggregated data and health disparities. Blog BMG Global Health. Retrieved from https://blogs.bmj.com/bmjgh/2020/03/24/sex-gender-and-covid-19-disaggregated-dataand-health-disparities/.

Thakur, V., \& Jain, A., (2020). COVID 2019-Suicides: A global psychological pandemic. Brain, Behaviour, and Immunity. https://doi.org/10.1016/j.bbi.2020.04.062

UN Women (2020). Violence against women and girls: the shadow pandemic. Retrieved from https://www.unwomen.org/en/news/stories/2020/4/statement-ed-phumzile-violence-againstwomen-during-pandemic.

UN Women \& WHO (2020). Violence Against Women and Girls: Data Collection during COVID-19. Retrieved from https://www.unwomen.org/-/media/headquarters/attachments/sections/ library/publications/2020/vaw.

van Osch, T. (2020). The gender impact of Coronavirus: How to move to an economy that cares for people and the planet. Retrieved from https://wideplus.org/wpcontent/uploads/2020/03/The-gender-impact-of-Corona-Virus.pdf.

Wenham, C., Smith, J., and Morgan, R. (2020). COVID-19: the gendered impacts of the outbreak. The Lancet, 395, 846-848. https://doi.org/10.1016/S0140-6736(20)30526-2

World Bank Group (2020). Gender dimensions of the COVID-19 pandemic. Retrieved from https://openknowledge.worldbank.org/bitstream/handle/10986/33622/Gender-

Dimensions-of-the-COVID-19-Pandemic.pdf. 